\title{
Performance of working memory of musicians and non-musicians in tests with letters, digits, and geometrical shapes
}

\author{
Artem Okhrei*, \\ Tetiana Kutsenko, \\ Mykola Makarchuk \\ Taras Shevchenko National \\ University of Kyiv, \\ Educational and Scientific \\ Centre "Institute of Biology", \\ Academician Glushkov Ave. 2, \\ 03022 Kyiv, Ukraine
}

Background. Recent researches points out that musical training might have a positive influence on human cognitive domain and working memory improvements are thought to mediate this influence. However, there is some discrepancy among results of researches dealing with working memory testing of musicians and non-musicians.

Materials and Methods. The participants were the students who for 10-15 years had been engaged in regular musical practice (musicians) and their peers who had no previous musical experience (non-musicians). A computerized working memory test for letters, digits and shapes with successive presentation of stimuli was applied in the current study.

Results. Musicians and non-musicians did not differ in the overall number of mistakes and latency of responses made in all subtests for letters, digits and shapes. The left hand made significantly more mistakes than the right one in both groups, but this regularity was more typical of non-musicians. The right hand responded faster than the left one while doing all subtests in both groups, but such a motor asymmetry was more evident for nonmusicians. Musicians mostly did not demonstrate an increase in latency of responses with task complexity growing from set to set of stimuli, while non-musicians did.

Conclusions. The efficiency of working memory test performance did not differ among musicians and non-musicians. Musicians have tighter interhemispheric cooperation during the memory test and that was indicated by a lesser motor asymmetry. Musicians have almost equal latency of responses regardless of task complexity, while non-musicians require more time for responding to stimuli during growing task complexity, probably because of using different search patterns in working memory or tighter interhemispheric cooperation.

Keywords: working memory, motor asymmetry, musicians, nonmusicians

* Corresponding author. Email: ochrei.artem@gmail.com 


\section{INTRODUCTION}

A growing number of studies offer evidence in favour of a positive influence of musical training on human cognitive functions. It is known that in comparison with people who do not have any vocal and instrumental experience, musicians demonstrate better results in verbal memory tests (Ho et al., 2003), visuospatial reasoning (Patston et al., 2007a), higher mathematical (Gardiner et al., 1996; Cheek, Smith, 1999; Graziano et al., 1999) and reading abilities (Moreno et al., 2009), and even a higher IQ (Nering, 2002; Schellenberg, 2004). However, the question of such a cognitive enhancement of musicians is still unclear and the neurophysiological mechanisms mediating these changes are unknown.

As the one of possible explanations, George and Coch (2011) suggested musical training to improve working memory (WM) and executive functions, which in turn might form a basis for further increase of cognitive potential of musicians in comparison with non-musicians. Indeed, several researches present data regarding a positive influence of regular musical training on efficiency of the function of WM components: the phonological loop (Lee, 2007; Franklin et al., 2008; George, Coch, 2011), the visuospatial sketchpad (George, Coch, 2011), and the central executive (Franklin et al., 2008; Parbery-Clark et al., 2009; George, Coch, 2011). However, there are some contradictions among these researches. In particular, Lee et al. (2007) found musicians to perform better than non-musicians in tests with the engagement of the phonological loop, but demonstrated no differences in tests for the central executive and the visuospatial sketchpad between two groups (Lee et al., 2007). Similarly, the research conducted by Strait et al. (2010) did not find significant differences among adult musicians and non-musicians while doing the task requiring the central executive. On the other hand, George and Coch (2011) represent data demonstrating that musicians, unlike non-musicians, performed better in tests for the phonological loop, the visuospatial sketchpad, and the central executive.
Taking into consideration the said contradictions in the current study we decided to continue a clarification of the influence of regular and continuous musical training on WM as one of the basic human cognitive functions. In addition, we decided to explore the interhemispheric interaction during the WM test, because WM components by themselves have different functional lateralization (Baddeley, 2000). And again, it is known that during some cognitive tasks brain hemispheres work in a tight contact, thus reaching a higher efficiency of performance (Weissman, Banich, 2000), while regular musical training might lead to a decrease in functional asymmetry of musicians (Kostandov, 1992; Okhrei et al., 2012).

\section{MATERIALS AND METHODS}

Participants were 64 right-handed students of both sexes, from 17 to 23 years of age. The musicians' group $(n=28)$ consisted of students of the National Music Academy of Ukraine, who had from 10 to 14 years of musical experience. The non-musicians' group $(n=36)$ was represented by students of the Scientific and Educational Centre "The Institute of Biology" of Kyiv National Taras Shevchenko University with no previous musical or singing experience. All participants had normal hearing and no previous neurological disorders.

To estimate WM and interhemispheric interactions of musicians and non-musicians, we used a computerized test developed at the Department of Human and Animals Physiology of the Scientific and Educational Centre "The Institute of Biology" of Kyiv National Taras Shevchenko University (Filimonova et al., 2006). This test consists of three successive subtests. In the first subtest the working memory for visually-presented consonants was assessed. A participant was situated in a quiet room in front of a computer monitor, $50 \mathrm{~cm}$ from it. The set of consonants was presented at the centre of the monitor and the quantity of letters was increasing progressively from two to seven. The exposure of each stimulus was $1.5 \mathrm{~s}$, after which the letters faded out, the test 
letter appeared, and the testee was required to answer whether the test letter was present in the previous set. "Yes" responses had to be given with the right hand by pressing the " " key on the computer keyboard, while "no" responses had to be given with the left one by pressing the " $\mathrm{z}$ " key. The second and the third subtests were organized in the same way. The second subtest aimed at assessing the working memory for visually-presented digits, and the third one for visually-presented geometrical shapes (Fig. 1).

We registered the latency of correct responses (with the precision of $10 \mathrm{~ms}$ ) and the quantity of incorrect responses as the criteria of WM efficiency.

Statistical processing was carried out by STATISTICA software (StatSoft, USA, 2001). The normality of data distribution was examined using the Shapiro-Wilk test. Whereas

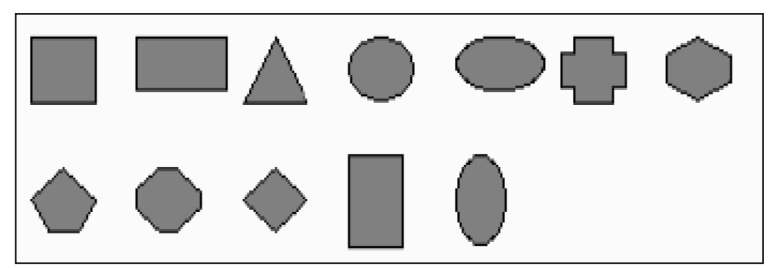

Fig. 1. Types of shapes applied in the third subtest (reprinted with permission from Filimonova et al., 2006) the greater part of data had non-normal distribution, we used median (Me), lower and upper quartile $([25 ; 75])$ for descriptive statistics. We used the Mann-Withney test to compare independent data (groups), and the Wilcoxon test for dependent ones. The critical level of significance $(p)$ was accepted as 0.05 and was marked as " $*$ " on plots $(p<0.01$ was marked as " $* *$ ", $p<0.001$ was marked as “***”).

\section{RESULTS AND DISCUSSION}

It was revealed that the overall number of mistakes made by musicians and non-musicians during all subtests did not differ between the two groups. However, the number of incorrect reactions depended on the type of the subtest: the lowest number of mistakes was made in the subtest dealing with letters, and the highest one in the subtest dealing with geometrical shapes (Fig. 2).

It should be noted that the contribution of the left and right hands concerning the general quantity of mistakes differed: the left hand made significantly more mistakes than the right hand in all subtests (Table). Such regularity was more typical of the non-musicians' group in comparison with musicians, especially in the subtest of digits.

We also revealed that the right hand responded faster than the left hand during all

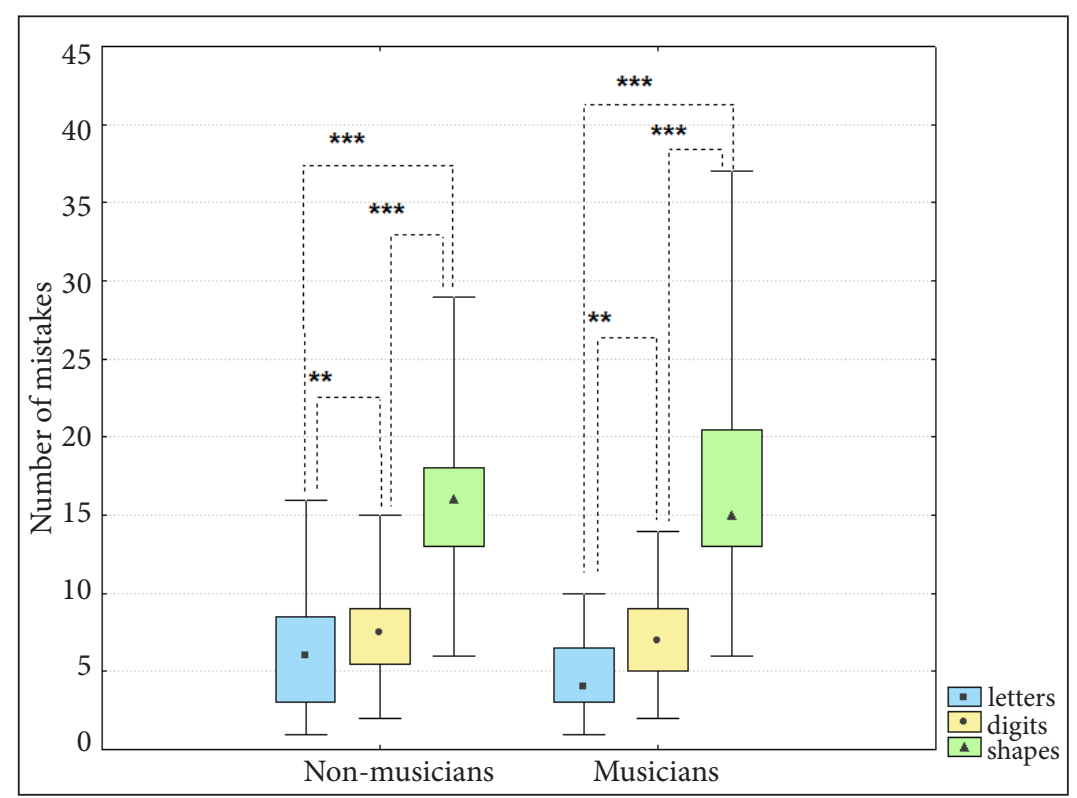

Fig. 2. The overall number of mistakes made by musicians $(n=28)$ and non-musicians $(n=36)$ during all subtests of working memory 
Table. The quantity of incorrect responses of the left and right hands of musicians and non-musicians

\begin{tabular}{|c|c|c|c|c|c|c|c|c|}
\hline & & & \multicolumn{6}{|c|}{ The quantity of stimuli } \\
\hline & & & 2 & 3 & 4 & 5 & 6 & 7 \\
\hline \multirow[t]{4}{*}{ Lt } & \multirow[t]{2}{*}{ MS } & $\mathrm{L}$ & 0 & 0 & 0 & $0[0 ; 0.5]$ & $0[0 ; 1]$ & $0.5[0 ; 1]$ \\
\hline & & $\mathrm{R}$ & $0[0 ; 1]$ & 0 & 0 & 0 & $0[0 ; 1]$ & $1[0 ; 2]$ \\
\hline & \multirow[t]{2}{*}{ Nms } & $\mathrm{L}$ & $0[0 ; 0.5]$ & $0[0 ; 0.5]$ & 0 & $0[0 ; 1]^{*}$ & $0[0 ; 1]$ & $1[0 ; 1.5]$ \\
\hline & & $\mathrm{R}$ & $0[0 ; 1]$ & $0[0 ; 1]$ & $0[0 ; 1]$ & 0 & $0[0 ; 1]$ & $0.5[0 ; 2]$ \\
\hline \multirow[t]{8}{*}{ Dg } & \multirow{2}{*}{ Ms } & $\mathrm{L}$ & 0 & $0[0 ; 1]^{*}$ & $0[0 ; 1]$ & $1[0 ; 1]^{\star *}$ & $1[0 ; 2]^{*}$ & $1.5[1 ; 3]$ \\
\hline & & $\mathrm{R}$ & 0 & 0 & 0 & 0 & $0[0 ; 1]$ & $1[0 ; 2]$ \\
\hline & \multirow[t]{2}{*}{ Nms } & $\mathrm{L}$ & $0[0 ; 1]$ & $0[0 ; 1]^{*}$ & $0[0 ; 1]^{*}$ & $1[0 ; 1]^{*}$ & $1[1 ; 2]^{\star *}$ & $2[1 ; 2.5]^{* * *}$ \\
\hline & & $\mathrm{R}$ & 0 & 0 & 0 & $0[0 ; 1]$ & $0[0 ; 1]$ & $1[0 ; 1]$ \\
\hline & \multirow[t]{2}{*}{ Ms } & $\mathrm{L}$ & $0[0 ; 1]$ & $1[0 ; 1]$ & $1.5[1 ; 2]$ & $2[1 ; 2]$ & $3[1 ; 3.5]^{\star}$ & $2[1 ; 3]$ \\
\hline & & $\mathrm{R}$ & $0[0 ; 1]$ & $0[0 ; 1]$ & $1[0 ; 2]$ & $2[1 ; 2]$ & $1.5[1 ; 2]$ & $1[1 ; 2]$ \\
\hline & \multirow[t]{2}{*}{$\mathrm{Nms}$} & $\mathrm{L}$ & $0[0 ; 1]$ & $0[0 ; 1]$ & $2[1 ; 2.5]^{*}$ & $2[1 ; 3]^{\star *}$ & $2[1 ; 2.5]$ & $2[1 ; 3]$ \\
\hline & & $\mathrm{R}$ & $0[0 ; 1]$ & $0[0 ; 1]$ & $1[0 ; 1.5]$ & $1[0 ; 2]$ & $1[0 ; 2]$ & $2[1 ; 3]$ \\
\hline
\end{tabular}

Legend: Lt - letters subtest, Dg - digits subtest, Fg - shapes subtest; Ms - musicians, Nms - non-musicians; L - left hand, $\mathrm{R}$ - right hand. Significant differences are marked between the mistakes made by the left and right hands within each group.

subtests (Figs. 3-5). It should be noted that this regularity is more pronounced in non-musicians than in musicians.
Besides, we also revealed that successive increasing of latencies of correct responses from a set of two stimuli to a set of seven stimuli

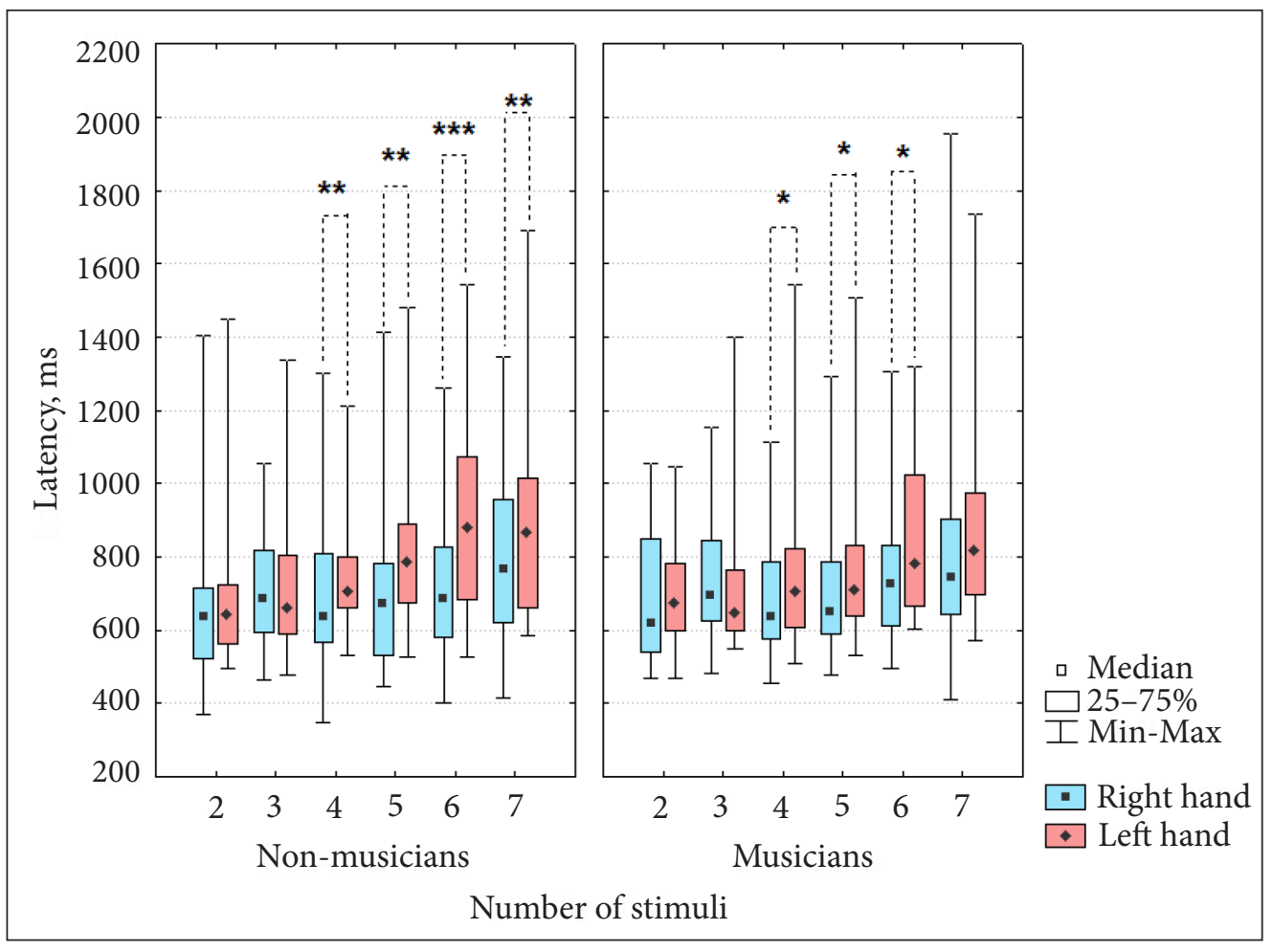

Fig. 3. The latency of correct responses of musicians and non-musicians in the subtest with letters 


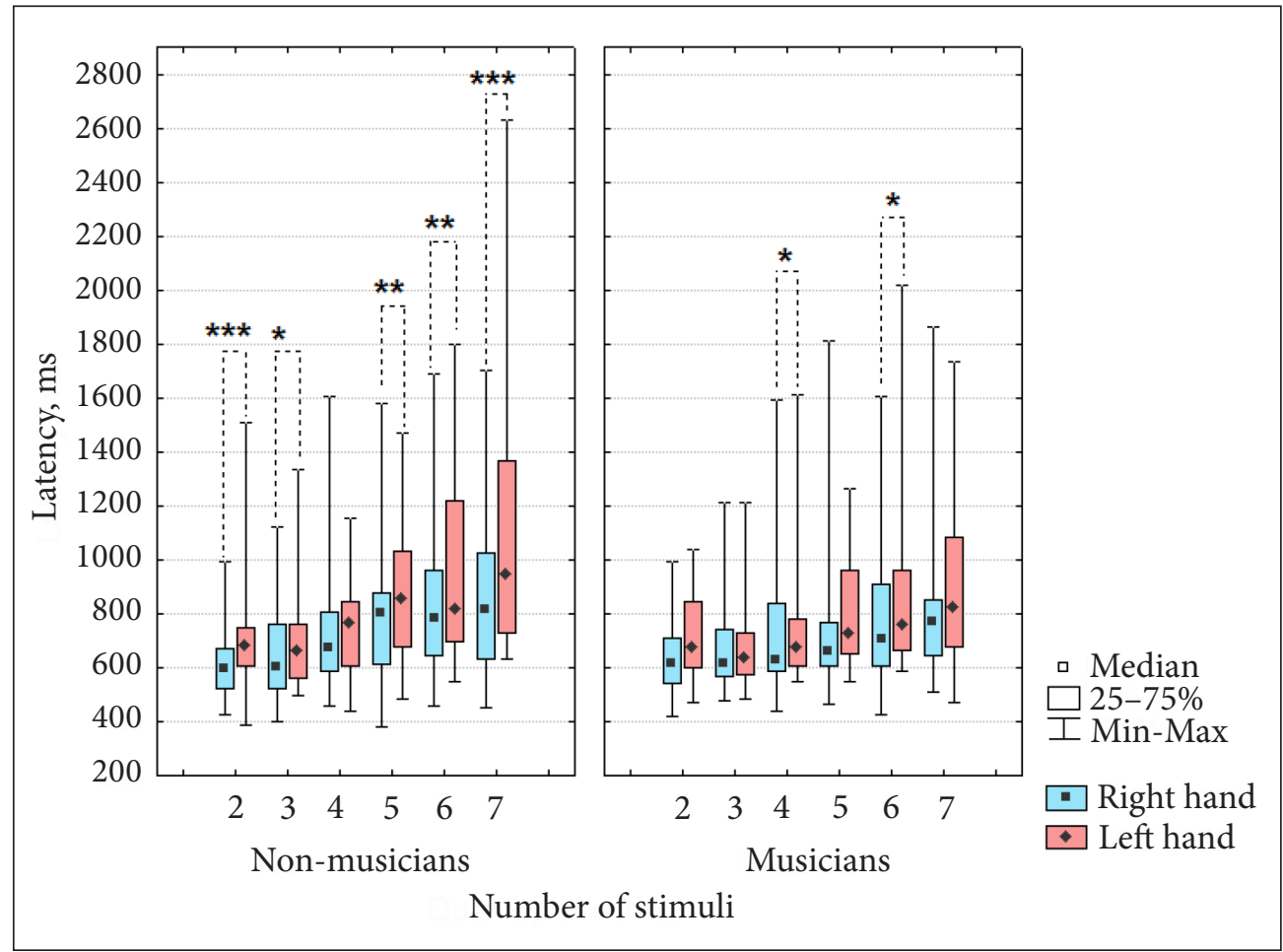

Fig. 4. The latency of correct responses of musicians and non-musicians in the subtest with digits

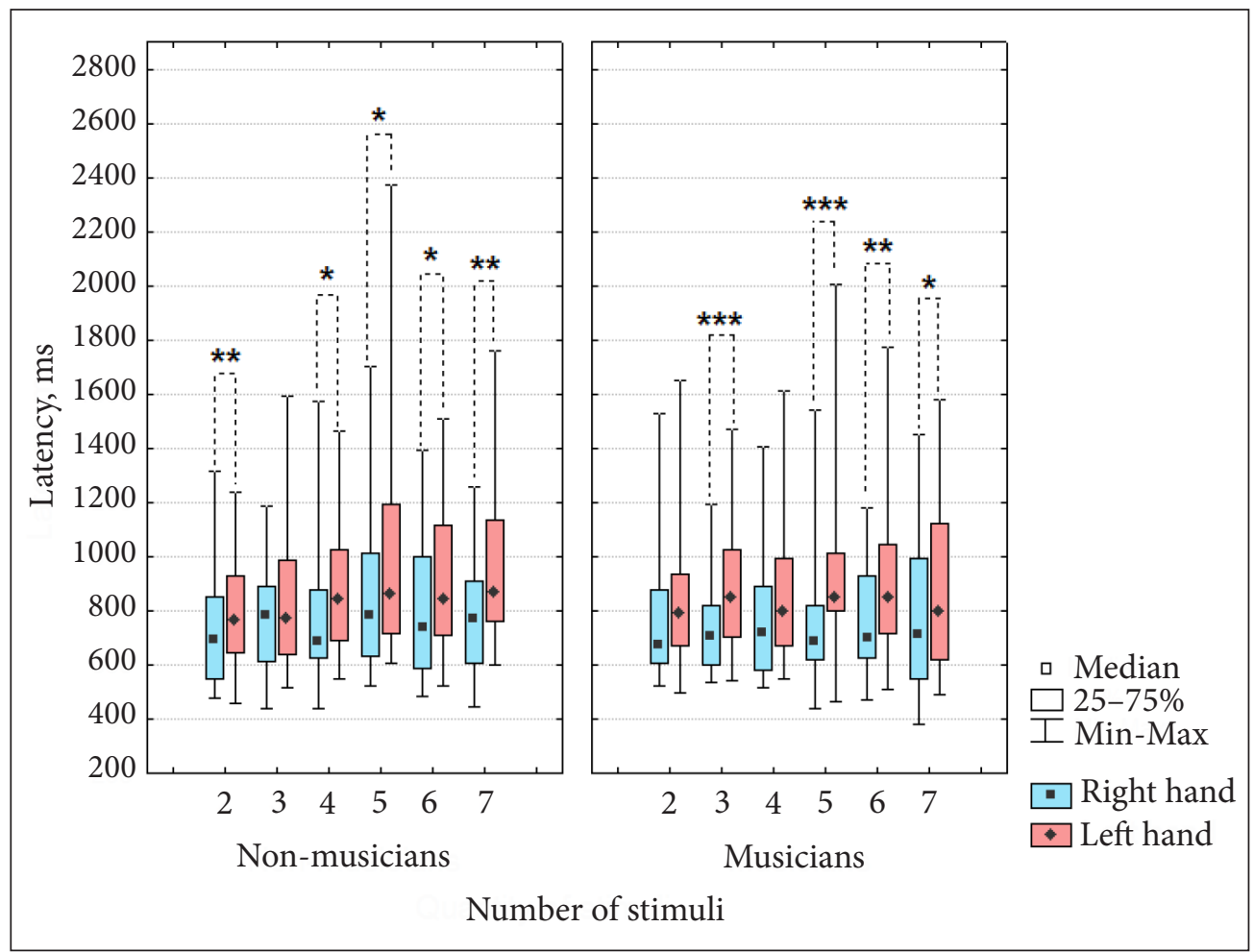

Fig. 5. The latency of correct responses of musicians and non-musicians in the subtest with geometrical shapes 
is not linear. For example, response latencies among non-musicians increase in a step-like manner depending on the growing complexity of the task (Fig. 6). On the other hand, musicians only demonstrated the increase in latency of the right hand for a set of three stimuli. However, the latency of the right hand decreased in the next set of four stimuli.

In the subtest dealing with digits (Fig. 7), non-musicians also demonstrate a progressive increase in response latencies of both the right and left hands whereas musicians show only an increase in left-hand latency in the last set that consisted of seven stimuli.

In the subtest dealing with geometrical shapes the increasing of latencies of non-musicians was revealed in the set of three stimuli (right hand) and in the set of five stimuli (left hand) (Fig. 8). The musicians did not demon-

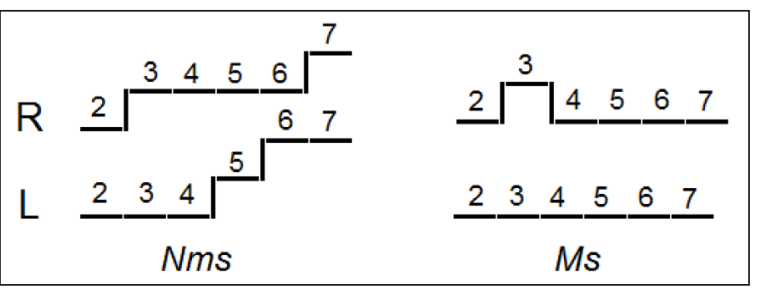

Fig. 6. The general scheme of increasing of latencies in non-musicians (left) and musicians (right) in subtest with letters. Numbers denote the quantity of stimuli in the set. Steps reflect significant increase of latency compared with the corresponding value of the previous set. $\mathrm{R}$ - right hand, L - left hand; Nms - non-musicians, Ms - musicians

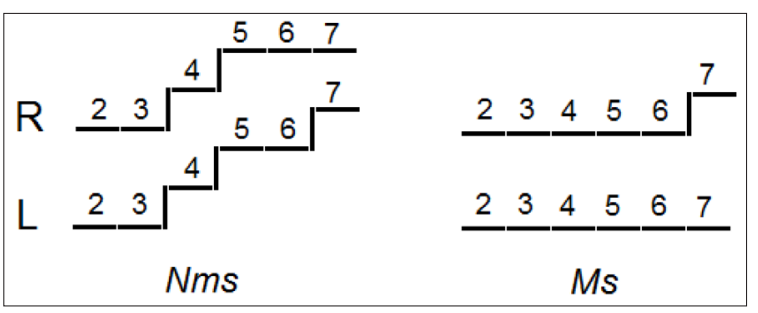

Fig. 7. The general scheme of the increase in latencies of non-musicians (left) and musicians (right) in the subtest with digits. The legend is the same as in Fig. 6

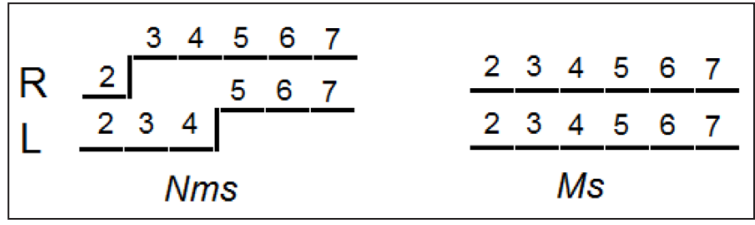

Fig. 8. The general scheme of increasing of latencies of non-musicians (left) and musicians (right) in the subtest with shapes. The legend is the same as in Fig. 6

strate any increasing of latencies from the first to the final set of stimuli. However, there were no differences of latencies for both hands between two groups during all the subtests.

To summarize, judging from the total number of mistakes musicians and non-musicians do not differ in working memory efficiency for visually-presented letters, digits and shapes.

However, the types of stimuli mentioned above form a sequence by the number of mistakes: letters $->$ digits $->$ geometrical shapes (Fig. 2). This fact can be connected with different mechanisms that mediate the storing of each type of information. For example, letters can be perceived either orally or in written form. Thus, visually-presented letters are stored not only in visuospatial sketchpad (right hemisphere), but also in the phonological loop (left hemisphere), where they get in by means of information recoding (Baddeley, 1992). In this way, the same set of letters acquires two forms - as a visual representation (right hemisphere) and as a piece of information that is "pronounced" by the internal voice in the phonological loop and which is constantly repeated in order not to be forgotten (left hemisphere). Moreover, a group consisting of several letters might occasionally combine and form an item of a higher order, which can be distinguished easily and remembered as a whole (for example, as a well-known abbreviation).

What was said above about letters can be applied to digits, which, apart from the visuospatial sketchpad, can be stored in the phonological loop by means of recoding mechanism. 
However, since the names of digits consist of several letters (e. g., "one", "eight", "four"), the full loop of repetition of one set in the phonological loop requires more time. Besides, taking into consideration the fact that the information in the phonological loop can be stored only within two seconds without repetition (Baddeley, 1992), the rehearsal mechanism cannot work effectively with big sets of digits (4-7 items of information) and this will cause an increase in the number of mistakes during the subtest of digits in comparison with the subtest of letters. In their turn, geometrical shapes seem to be stored only in the visuospatial sketchpad (right hemisphere) and are hardly verbalized, like letters or digits are. Consequently, the number of mistakes rises in the subtest dealing with shapes, because only one visual representation of digits is created.

The sequence of the rise of mistakes (letters $\rightarrow$ digits $\rightarrow$ geometrical shapes) was observed in both musicians and non-musicians. Taking into consideration the fact that there was no difference between both groups in terms of the number of mistakes, the conclusion can be made that, regardless of their musical experience, participants have the same efficiency of WM functioning and a common pattern of its work.

These results are consistent with the data of other authors who found no differences of WM functioning in terms of the number of mistakes or tests scores between musicians and non-musicians (Brochard et al., 2004; Strait et al., 2010).

However, as it was mentioned above, some researches present evidences that, unlike nonmusicians, musicians reach higher results in WM tests (Franklin et al., 2008; ParberyClark et al., 2009; George, Coch, 2011). The type of stimuli presentation might be a reason of such a discrepancy. It should be noted that in our research the sets of stimuli were presented not successively, one by one (the Stenberg paradigm (Sternberg, 1966)), but simultaneously (Sperling paradigm (Sperling, 1960)). As far as we know, psychophysiological researchers who worked with the influence of musical experience on WM functioning used the paradigm of successive but not simultaneous stimuli presentation (Lee et al., 2007; Franklin et al., 2008; Parbery-Clark et al., 2009; Strait et al., 2010; George, Coch, 2011). Besides, in our case the exposure of each set of stimuli was $1.5 \mathrm{~s}$, after which the participants were instructed to react immediately. This circumstance minimizes the chance of rehearsing the information several times before giving an answer. Thus, the differences in the methodical approach between our research and the previous ones could influence the final result of the WM test.

In our study we also revealed that the left hand makes mistakes more frequently than the right hand (Table) and this regularity is more typical of the non-musicians' group. Besides, the left hand has longer latency (Figs. $3-5)$ than the right hand, and it is also more pronounced for the non-musicians' group. Several important statements might result from such a pattern of motor asymmetry. First of all, shorter latencies of the right hand ("yes" answer) in comparison with the left hand ("no" answer) might demonstrate early termination of search in the representation of stimuli in WM when the test letter is found (Kutsenko, Filimonova, 2006). Yet Kutsenko (2010), who conducted similar test with students (nonmusicians) and reversed the type of reaction (right hand responded "no", left hand responded "yes"), revealed that the left hand has longer latency than the right hand even in the case of providing "yes" answers. Probably the explanation of such regularity might be the leftward lateralization of motor control. According to Derakhshan (2010), the command for movement is formed in the dominant hemisphere (the left one in $80 \%$ of the population). Because of the transcallosal delay, motor reactions carried out by the right hand are faster than by the left hand. Taking into consideration the data described above and the results of our research, we can state that a lower degree of the motor asymmetry of musicians during WM tests can probably be caused by a shorter transcallosal delay and more pronounced interhemispheric cooperation. Indeed, researches conducted by Patston et al. (2007a) are partially consistent with our data. These authors found 
musicians to demonstrate a less pronounced functional asymmetry during the line bisection task (Patston et al., 2007a). Also, musicians did not demonstrate interhemispheric differences of N1 component of visual event-related potentials elicited by monocular stimulation. In turn, non-musicians demonstrated $\mathrm{N} 1$ to appear earlier in the left hemisphere (Patston et al., 2007b). Thus, these results point out that musicians have more pronounced bilateral connectivity than non-musicians (Patston et al., 2007b).

In this study we also revealed the fact of a step-by-step rise of latencies of both hands of musicians and non-musicians (Figs. 6-8). We found that latency of responses of nonmusicians rises gradually during the increase in the number of stimuli in a set. In turn, musicians hardly demonstrated a gradual rise of latencies during increasing complexity of the subtests. We suppose that the rise of latency of non-musicians with every next set of stimuli can be caused by growing time demands needed for stimuli evaluation and giving a response. On the other hand, musicians in general had the same time demands during all subtests. This finding might point to different strategies of search in representations of stimuli in WM of musicians and non-musicians.

\section{CONCLUSIONS}

The efficiency of working memory test performance does not differ between musicians and non-musicians. Musicians have a lower degree of motor asymmetry than non-musicians, and it suggests that musicians have tighter interhemispheric cooperation during working memory test. Non-musicians require more time for giving response with increasing of number of stimuli in a set. In turn, musicians do not demonstrate growing latency of both hands from one set to another, which can probably be explained by using different strategies of search in working memory or tighter interhemispheric cooperation.

Received 16 August 2016 Accepted 20 November 2016

\section{References}

1. Baddeley AD. The episodic buffer: a new component of working memory? Trends Cogn Sci. 2000; 4(11): 417-423.

2. Baddeley AD. Working memory. Science. 1992; 225(5044): 556-9.

3. Brochard R, Dufour A, Despres O. Effect of musical expertise on visuospatial abilities: Evidence from reaction times and mental imagery. Brain and Cognition. 2004; 54: 103-9.

4. Cheek JM, Smith LR. Music training and mathematics achievement. Adolescence. 1999; 34(136): 759-61.

5. Derakhshan I. It Is All Quiet in the Minor Hemisphere: An Investigation into the Laterality of Consciousness, Attention and Vision in the Human Brain. Biomedicine International. 2010; 1: 3-15.

6. Filimonova N, Kutsenko T, Makarchuk M. [Features of processing of visual verbal and non-verbal information in human working memory.] Physics of the Alive. 2006; 14(3): 75-86. Ukrainian.

7. Franklin MS, Rattray K, Moore KS, Moher J, Yip C, Jonides J. The effects of musical training on verbal memory. Psychology of Music. 2008; $1-13$.

8. Gardiner MF, Fox A, Knowles F, Jeffrey D. Learning improved by arts training. Nature. 1996 May 23; 381(6580): 284.

9. George EM, Coch D. Music training and working memory: An ERP study. Neuropsychologia. 2011; 49: 1083-94.

10. Graziano AB, Peterson M, Shaw GL. Enhanced learning of proportional math through music training and spatial-temporal training. Neurological Research. 1999; 21(2): 139-52.

11. Ho Y, Cheung M, Chan AS. Music training improves verbal but not visual memory: crosssectional and longitudinal explorations in children. Neuropsychology. 2003; 17(3): 439-50.

12. Kostandov EA. The factor of dynamism in functional asymmetry of brain hemispheres. Human Physiology. 1992; 18(3): 17-24. 
13. Kutsenko T, Filimonova N. [Features of visual stimuli processing in short-term memory in the case of simultaneous presentation.] Physiological Journal. 2006; 52(2): 75-76. Ukrainian.

14. Kutsenko T. ["Yes" and "No" reactions by right and left hand during investigating working memory for letters and digits.] Vysnik Luganskogo natsionalnogo universiteta imeni Tarasa Shevchenka. 2010; 21(208): 60-66. Ukrainian.

15. Lee $\mathrm{Y}, \mathrm{Lu} \mathrm{M}, \mathrm{Ko} \mathrm{H}$. Effects of skill training on working memory capacity. Learning and Instruction. 2007; 17: 336-44.

16. Moreno S, Marques C, Santos A, Santos M, Castro SL, Besson M. Musical training influences linguistic abilities in 8-year-old children: More evidence for brain plasticity. Cerebral Cortex. 2009; 19: 712-23.

17. Nering ME. The effect of piano and music instruction on intelligence of monozygotic twins. Dissertation Abstracts International Section A: Humanities and Social Sciences. 2002; 63(3-A): 812.

18. Okhrei AG, Kutsenko TV, Makarchouk NE. Specificity of Auditory Cognitive Evoked Potentials in Musicians. Neurophysiology. 2012; 43(6): 507-9.

19. Parbery-Clark A, Skoe E, Lam C, Kraus N. Musician Enhancement for Speech-In-Noise. Ear \& hearing. 2009; 30(6): 653-61.

20. Patston LL, Hogg SL, Tippett LJ. Attention in musicians is more bilateral than in non-musicians. Laterality. 2007; 12(3): 262-72.

21. Patston LM, Kirk IJ, Rolfe MS, Corballis MC, Tippett LJ. The unusual symmetry of musicians: Musicians have equilateral interhemispheric transfer for visual information. Neuropsychologia. 2007; 45: 2059-65.

22. Schellenberg EG. Music lessons enhance IQ. Psychological Science. 2004; 15(8): 511-4.

23. Sperling G. The information available in brief visual presentations. Psychological Monographs: General and Applied. 1960; 74(11).

24. Sternberg S. High speed scanning in human memory. Science. 1966; 153: 652-4.
25. Strait DL, Kraus N, Parbery-Clark A, Ashley R. Musical experience shapes top-down auditory mechanisms: Evidence from masking and auditory attention performance. Hearing Research. 2001; 261: 22-9.

26. Weissman D, Banich M. The cerebral hemispheres cooperate to perform complex but not simple tasks. Neuropsychology. 2000; 14: 41-59.

\section{Artem Okhrei, Tetiana Kutsenko, Mykola Makarchuk}

\section{MUZIKANTŲ IR NEMUZIKANTŲ TRUMPA- LAIKĖS ATMINTIES NAŠUMAS ATLIEKANT RAIDŽIŲ, SKAIČIŲ IR GEOMETRINIŲ FIGŪRU TESTUS}

\section{Santrauka}

Naujausi tyrimai rodo, kad muzikos mokymasis gali turèti teigiamą poveikį žmogaus kognityvinei sričiai ir trumpalaikès atminties gerinimui. Pastebèta keletas neatitikimų tarp muzikantų ir nemuzikantų trumpalaikès atminties tyrimų rezultatų. Šiame straipsnyje aprašomas tyrimas, atliktas su reguliariai (10-15 metų) muzikuojančiais studentais ir ju bendraamžiais be ankstesnès muzikinès patirties. Tyrimo metu buvo taikytas kompiuterizuotas trumpalaikès atminties našumo raidžių, skaičių ir figūrų testas. Nustatyta, kad bendras klaidų kiekis ir latentinè reakcija, sprendžiant visus raidžių, skaičių ir figūrų testus, tiek muzikantų, tiek ir nemuzikantų nesiskyrè. Kairioji ranka klydo gerokai dažniau negu dešinioji abiejose tiriamų studentų grupèse, tačiau tai labiau buvo būdinga nemuzikantams. Dešinioji ranka reagavo greičiau už kairiąją abiejose tiriamų studentų grupèse, tačiau tokia motorinè asimetrija nemuzikantų buvo daug akivaizdesnè. Muzikantų, priešingai nei nemuzikantų, latentinè reakcija dažniausia negreitejo.

Raktažodžiai: trumpalaikè atmintis, motorinè asimetrija, muzikantai, nemuzikantai 